\title{
Practical theology as embodiment of Christopraxis- servant leadership in Africa
}

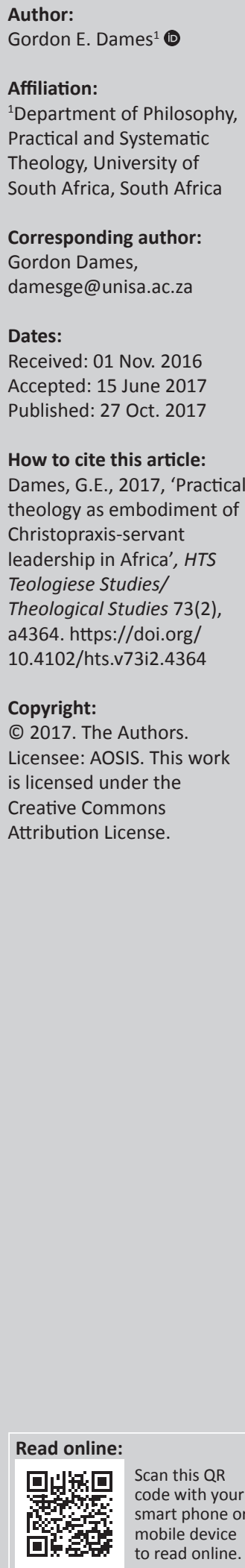

This article proceeds from the aim to revitalise the value of a service ethic for human well-being and the common good of all. The service delivery crisis in South Africa and Africa forms the context. A contemporary example of an embodied practical theology of service is offered, followed by a theological and social analysis of service delivery in South Africa. A theoretical service ethic framework with special reference to practical theology as a living Christopraxis is discussed. Finally, the value of diaconology as a science of service is presented, followed by the conclusion.

\section{Introduction}

There are multiple contemporary examples of dysfunctional communities, institutions, people and leaders in local African realities (Mwambazambi 2013:154). Leaders are called upon to promote a lasting legacy of existential, moral and spiritual change in society. There is a need for an inherent ethical imperative to transform Africa in terms of its politics, economics and society (Mwambazambi 2013:155). The foundations of African society, the family, African traditional religion, culture, customs, morals and the Church 'are shaken by the assaults of materialism, of mental alienation and of ideologies which are opposed to their preservation' (Mwambazambi 2013:154). One of the reasons may be in what Adhiambo (2012:157, 162) maintains that 'African leaders have been the architects of their own misfortunes'. Political leaders in, for example, Kenya, have elevated themselves as kings and or chiefs. ${ }^{1}$ Servant leadership may offer a solution to these self-imposed notions of superiority (Adhiambo 2012:157). Suffice it to say that the vacuum of servant leadership and consequent misfortunes of African leaders leaves much to desire:

\footnotetext{
... the inability of leaders to maintain sustainable solutions to hunger, poverty and unemployment; mismanagement of resources in Africa; and flaws in systems that encourage favouritism, nepotism, tribalism, political differences, ideological and religious discrimination; a lack of capacity to manage society; poor leadership, poor planning, greed and worship of material things lack or failure to professional ethics; poor delivery of services and rampant human capital flight; as well as negative ethnicity culminating in wars and ethnic clashes. (pp. 157-158, 164)
}

Another reason lies in what Mveng (in Rwiza 2008:238-239) refers to as the African person's anthropology as an 'anthropological poverty' and an emerging crucial issue: 'it is the dispossession not only of the continent's material resources, but also of its cultural and moral forces, its very soul'. The public response of the former finance minister of South Africa, Pravin Gordhan, echoed the same concern when he announced after his dubious dismissal: 'that our souls are not for sale' (Munusamy 2017). Anthropological poverty refers to:

\footnotetext{
... when persons are deprived not only of goods and possessions of a material, spiritual, moral, intellectual, cultural, or sociological order, but of everything that makes up the foundation of their being-in-world and the specificity of their 'ipseity' as individual, society, and history. (Rwiza 2008:238)
}

Hence, there is need for the enhancement of servant leadership to reconstruct pervasive poor living conditions by providing essential services to African communities in improving quality of life (Adhiambo 2012:158). Adhiambo (2012:159, 161) holds that undesirable socio-economic, cultural and political challenges can be redressed through education and development undergirded by a philosophy and practice of servant leadership. Service-oriented leadership requires leaders with humility and a clear understanding of their individual and communal purpose and values. 'Leaders who serve followers found the way to prevent power from corrupting their leadership' (Stanko in Adhiambo 2012:165). Servant leadership can be regarded as a revived kind of leadership model in terms of complex socio-economic and political realities in Africa. It prioritises 'serving others as the number one priority': 'Servant-leadership emphasises increased service to others; a 1.The term "chief' is a colonial imposed concept. A chief (kgosana) is the subordinate of the king (kgosi) 
holistic approach to work; promoting a sense of community; and the sharing of power in decision-making' (Spears in Adhiambo 2012:166). Such leadership values resonate with Kä Mana's (in Mwambazambi 2013:149) vision of a new reconstructed African society. It raises crucial questions: How do we realise these values today? How do we identify the traits of servant leadership? What are the essential characteristics of servant leadership as the key or guiding principles to African leaders? Robert Greenleaf's (in Adhiambo 2012:167-173) characteristics for servant leaders may present us with an answer to these questions, namely leaders' abilities of 'listening; empathy; healing; awareness; persuasion; conceptualisation; stewardship and; more importantly a commitment to the growth of people'. The achievement of these leadership traits relies on firm leadership and drastic measures to rid Africa of global dubious leadership and institutions which lie at the root of its demise:

Today's dominant culture of lethargy in the face of oppression and suffering in the Third World, of consumerism in the North and of ideological conflict world-wide must be overthrown and replaced by a culture of commitment of the service of the whole human person. (Rwiza 2008:246)

The complex and pervasive social and political challenges in Africa call for servant leadership to enhance Rwiza's (2008) plea for a culture of commitment of the service of the whole human person.

\section{Existential service delivery challenges}

Such a service culture seems far-fetched in terms of existential service delivery challenges in, particularly, South Africa. The practice of service in the light of recent violent service delivery protests in South Africa's local communities should not be regarded as only a topical focus of practical theology, neither is it just a political, social or economic obligation or mission (Swart 2013). It should essentially be a vocation, a calling grounded in divine spirituality and humanity (cf. Osmer 2008:183-184). It prompts questions such as: What is the primary calling of humanity? How is this vocation embodied within contemporary contexts? What role does practical theology play to inform and shape communities to embody its vocation? The example of the embodiment of a transformational service ethic by an academic and church leader below may offer some insight into these questions and demonstrate a deep-grounded practice of service during similar political and social conditions as today, more so, in the light of the 'spirit of the enclave' - a tendency of immigrating inwardly by the white (and a growing black) higher middle class in South Africa (Cilliers \& Nell 2014:101, 104-106). The aforementioned are 'avoidance of, the harsh realities of the South African context', an escape from socioeconomic responsibilities with its complex race relations and high levels of poverty and inequality (Cilliers \& Nell 2014:96, 105). Cilliers and Nell's (2014:94) concerns about what is happening with social transformation in South Africa relates to the lack of a good service ethic and ethos of serving the poor. It is for this reason that the above-mentioned example of a white Afrikaner male is used to demonstrate how a single white person can make a difference in society, especially, in the light of harsh conditions as during the liberation struggle in South Africa, as a 'model' of how contemporary South African citizens can contribute to social transformation in Africa.

Hence, the objective of this article is to re-accentuate a theological and social ethic of service for the well-being and common good of all.

\section{A contemporary example of an embodied practical theology of service}

The academic and church leader Gustav $\mathrm{Bam}^{2}$ joined the Faculty of Theology at the University of the Western Cape (UWC) as professor in practical theology, at the culmination of our liberation struggle in South Africa (Bam 1984:1). He exemplified a unique critical reflective and liberal action disposition by crossing his cultural and confessional safe haven, to embrace a culturally different and hostile confessional community (Furstenberg, Robinson \& Cloete 2009:1; Grove 2009:201). Protesting theology students at UWC challenged his and his colleagues' personal, cultural and theological integrity with a severe measure of discontent - demanding their immediate removal from the university (Grove 2009:201; Smit 2012:2). 'The critical lens of a hermeneutics of suspicion' characterised our academic and social transformation project (cf. Pui-lan 2005:60, 108; Smit 2009:158-159). They engaged in the decolonialisation of the curriculum, study material, theology education and the epistemologies held, at the time, by the whitelecturers. Pui-lan's (2005) own experienceencapsulates the intent of their activism to decolonialise theology education:

By documenting my critical engagement with postcolonial thought ... analysing colonial discourse ... deconstructing Western dominant regimes of knowledge ... examining the cultural terrain traversed by both the colonisers and colonised..., I hope to create a little more space to imagine that an alternative world and a different system of knowing are possible. (p. 3)

Activism for total liberation from colonial education became a lifelong process of critical analysis and deconstruction of 'Western dominant regimes of knowledge and culture' (Puilan 2005:3).

Bam, with the rest of his white colleagues, weathered those stormy episodes and became liberated from their own privileged backgrounds (Furstenberg et al. 2009:17, 21). Theology education at UWC was successfully decolonialised and transformed. ${ }^{3}$ However, these gains were offered at the

2.I use this as an example of a white South African male who has demonstrated an unselfish leadership responsibility and a rare ethic of service to humanity in spite of the potential of being rejected and endangered. Professor Gustav Bam (1984) was a former Dutch Reformed (DR) minister at the Andrew Murray congregation in Cape Town.

3.Theology students have read progressive and critically relevant interdisciplinary liberation literature as well as liberation and contextual theologies (cf. Boff 1986; Gutiérrez 1984; ICT 1984). Compare the sermon trials of students for insight to how they conceptualised and operationalised the contextual and liberation theology of our time. It is an example of the decolonialisation of theology education and theology praxes (church, society and academia) (Dreyer 1987). 
altar of colonialised education when some of the church and academic leaders opted to trade theology education at UWC for greener pastures at the Theology Faculty of the University of Stellenbosch (Hendriks 2007). Bam demonstrated a rare academic, scientific and pastoral sense of service - grounded in his faith in God and his calling to serve humanity for the common good (Bam 1984). Bam (1984), in a moment of truth, stood up in the Synod of the former Dutch Reformed Mission Church in Southern Africa, to declare apartheid a heresy and to call on the leaders of the church to an act of confession that apartheid, disunity, hatred and injustice are sins (Koopman 2008; Mentor et al. 1982; Smit 2012:3). This moment of truth in our recent past, together with his inaugural lecture (Bam 1984), testifies to a leader's unwavering sense of calling to serve humanity, even if it meant to part from your religious tradition. His is an example of altruism and egalitarianism in serving the interest of and uniting others in Christ (Manala 2010:5):

Servant leadership values and develops people, builds community, promotes the practice of authenticity, providing leadership for the good of followers and the sharing of power and status for the common good of each individual, the total organisation and those served by the organisation. The serving, caring, sharing and developing conduct of the leader are central in the servant leadership model. (Manala 2014:254-255)

The re-emphasis and application of the serving dimension of the church for the well-being of the broader society and the exploration of a new service ethic ${ }^{4}$ are sought. It should inspire religious and public institutions to foster the values and imperative of servant leadership (Manala 2014). Therefore, a narrow clerical or ecclesiological approach or the interplay between the different traditional action fields (kerygma/ preaching, leitourgia/worship, didache/teaching, paraklesis/ care and diakonia/service) of practical theology will be avoided. This article focuses on, but shifts also beyond (decentring), ${ }^{5}$ the church and deals with the question of diaconia in society. ${ }^{6}$ The broadening of the scope of practical theology places issues such as the role of religion in the public sphere and the relation between politics and religion and the economy and religion on the agenda of practical theologians. This broadened or public focus of practical theology renders a narrow diaconology or clerical paradigm impractical. The aforementioned is also critical to respond adequately to concerns of former president Thabo Mbeki about the failure of the African National Congress's (ANC) leadership to redress 'the scourge of endemic corruption' in South Africa:

He accused the ANC of drifting away from the ordinary working people and its historic task and raison d'etre, established over a

4.This concept does not relate to the Protestant philosophy of work ethic as a 'motive force' that advances the progress of Western civilisation (Gemper 1991:532). Service ethic, in this article, refers to both a divine and human empathy to serve the neighbour among us from a Christopraxis perspective: Work ethic is a system creating 'core-configuration' forming together with the civil liberties and freedom of trade the framework of a democratic and social state, based on a free marke economy (Gemper 1991:533). Conventional Protestant work ethic engenders 'a fluidity of activeness and a propensity to efficiency ... this moral belief started to develop on its own as soon as religious substratum lost its importance for people' (Gemper 1991:532).

5.See Van der Ven (in Hermans 2014:10).

6.Compare Dreyer (2016): 'Practical theology broadened its scope beyond the role of the pastor and the church to include the role of religion (faith) in society. Practical theology is therefore not only concerned with church life (ecclesiological approach), theology is therefore not only concerned with church life (ecclesiological approach),
but the connection between faith, church and community. How can we make the but the connection between faith, church and community.
Christian faith relevant in contemporary contexts?' (p. 2). century, of existing solely to serve the interests of the people. (Seale 2016:1) ${ }^{7}$

This is a new moment of truth, a status confessionis, in which society can no longer keep silent in the face of dangerous moral, political and economic atrocities. Political leadership in the country has 'abandoned their mandate of serving the people, and the corrosive levels of corruption and self-aggrandisement in the ANC-led government', according to Mbeki:

[T] he hard reality we face today is that our country is trapped in a general and deepening political, economic and social crisis which has, for many, begun to turn what was an age of hope into an age of despair. (Seale 2016:1)

This article, therefore, aims to rekindle hope in humanity and to revitalise a sense of service ethic to reshape the futures of poor people in South Africa and Africa.

\section{The challenge of practical theology in contemporary South Africa}

Practising practical theology during a time of multiple challenges for academic, public or secular and sacred leaders in South Africa is almost similar to the volatile atmosphere of the struggle for democratic freedom between the 1970s and the early 1990s (Furstenberg et al. 2009:20; Smit 2012:2, 6-11). The violent and destructive \#FeesMustFall protests by South African students on tertiary campuses across the country are a case in point (Govender 2016:2; Whittles 2016:3). The previous struggle for political liberation was an honourable mission! Our current struggle for moral, economic, cultural and political liberation, in terms of its mere existence, holds much contention in relation to the previous struggle for political liberation in South Africa:

South Africa's peaceful transition to a non-racist democracy has received world-wide accolades. Poor service delivery by the new leadership has, however, hindered much needed development in terms of the economic empowerment of ordinary people, leading to frequent incidents of protest action. (Manala 2014:249)

Swart (2013:2) also views service delivery in South Africa as a 'crisis'. He holds that service delivery has become a 'new' topical focus for practical theology in South Africa (Swart 2013:2). More so, it characterises the context within which practical theology functions as a complex and difficult reality that calls conventional philosophies and methods into question (Duncan 2016:21). Hence, a decolonialised epistemology and methodology that can reshape the current moral and political realities of our country is required. ${ }^{8}$ The

7.:[C]ontemporary South African politics continues to be refracted through articulations of national liberation, and the sense of betrayal and broken promises of the emancipatory project is clearly expressed by emergent grassroots socia movements' (Gibson 2011:3)

8.Africa's place (or non-place, or 'non-being') in the modern, globalised world has remained remarkably consistent since the period of decolonisation. Indeed, Africa's 'non-being' (in terms of capitalist investment and development) has simply been reinforced by globalisation and the policies that were meant to open Africa up to its benefits. Neoliberal structural adjustment simply widened inequalities and benefits. Neoliberal structural adjustment simply widened inequalities and increased pauperisation, and Africa has become naturalised as a basket case. Afte years of International Monetary Fund (IMF)/World Bank 'good governance' contingencies, the continent still suffers from ruthless and sometimes huckstering ruling elites. Moreover, since real decolonisation was defined by Fanon as a political, economic and psychological liberation - what Ngugi wa Thiong'o (1986 in Gibson 2011:4) calls 'decolonising the mind' - postcolonial Africa remains very much a product of the failure of decolonisation (Gibson 2011:4). 
unbalanced pedagogical shift from humaniora programmes to natural sciences, engineering and technology during the early 1990s may prove to be the single most destructive policy in our time (Department of Education 1996:12). It requires redress to reshape the moral fibre and spiritual landscape of our humanity in South Africa (cf. Koopman \& Vosloo 2002). Hence, African theologians should become catalysts and facilitators of change by leading the church and society 'to adapt to the new socio-economic and politicalcultural demands of society' (Mwambazambi 2013:149).

Practical theology, in the light of the aforementioned realities, has to engage with the social and human sciences in forging a radically new epistemology and methodology to address the complex challenges of our time. The reinvention of Marx's (in Gibson 2011:137) notion of 'practical-critical activity' as well as Fanon's 'radical mutation of consciousness and the emergence of a new language and a new vocabulary' for a service ethic for the common good - is required. The reconstruction of Africa necessitates 'a change of mentality' and 'socio-economico-political energies' (Kä Mana in Mwambazambi 2013:149). A new African society is needed based on authentic, patriotic, spiritual, human and cultural values. Edusa-Eyison (2008:110-111) calls on African leaders to ground their thinking and action for a better comprehension of human life in terms of the gospel message.

It is impossible to retain a practical theology tailored for a narrow clerical, academic or even confessional ecclesiological approach. Practical theology needs a critical engagement with neoliberal economic and political hegemonic practices to engender a new philosophy, epistemology and ontology of service delivery.

\section{A theoretical framework for service in practical theology}

The current service delivery crisis in South African and the resultant lack of a service ethic among its citizens require renewed practical theological theoretical, ontological and methodological research to rid itself from a 'non-being and basket case' typology. ${ }^{9}$ Leaders on all levels of society are in need of the decolonising of the mind by unlearning the current pervasive poor service ethos by relearning a new service ethic, and in learning how to maintain and sustain a progressive service ethic for the common good of all. The current vacuum of leadership with a healthy service ethos and service ethic, especially in terms of African wisdom and spiritual discernment to envision and realise a new African future, may be at the root of the leadership problems in Africa. The main reason for a lack of a healthy service ethic may lie in the ironic fact that the contribution of African wisdom to modernity comes from a tragic, festering wound of political, economic and cultural assault by the West, to say the least' (Vellem 2015:91). The language of ordinary humanity, truthfulness, divine spiritual and civil

9.The need for a theoretical core lies in the current pervasive leadership and institutional failures and dysfunctionality which urge us to unlearn the recurring and persistent poor service ethic and relearn a moral, ethical and spiritual service ethic for the common good. accountability should recount again in and through the lives of civil leaders, especially Christian religious leaders (Okambawa 2013:107).

Practical theology is not practical theology similar to practical exercises in the art to teach a group to preach, to conduct a pastoral discussing or to organise a congregation (Bam 1984:4). Practical theology raises numerous critical questions about its nature and objective, for example:

Practical theology locates itself within the diversity of human experience, making its home in the complex web of relationships and experiences that form the fabric of all that we know. The wide range of approaches and methodological positions apparent within the discipline reflects a variety of attempts to capture this diversity and complexity. (Swinton \& Mowat 2006:1)

Practical theology, in the light of diverse and complex lived experiences, has to adopt an interdisciplinary approach to redress the current political, economic and social impasse in South Africa.

\section{Practical theology as a living Christopraxis}

Practical theology as a living science holds the potential to be adaptive and vibrant in any circumstance, practice or context. It is what the whole of theology ought to be - practical theology - a living encounter between the Trinity and humanity and within different life settings among people in sacred and secular realities (cf. Immink 2005:1-2, 10). On the other hand, umunthu as the foundational philosophy of Malawian life can enrich practical theology in terms of human interaction and the articulation and reconstruction of the realities of African people:

it has been used to shape all spheres of life. It sustained life before colonialization, and continues to draw communities together even today, in the face of poverty, diseases and famine. (Kwiyani 2013:42-43)

It offers a wholesome and well-integrated system of support that takes care of life as a whole (Kwiyani 2013:43). It focuses on the spiritual and material needs of a community and simultaneously protecting the ecology and honouring the ancestors (Kwiyani 2013:43). More so, a new liberation embedded in Christopraxis and umunthu, is required.

Botman, other than recent research (Anderson 2001; Root 2014) was the first practical theologian in South Africa who introduced the Christopraxis approach in practical Theology.

The divine act of God consummated in Jesus Christ and continued through the power and presence of the Holy Spirit' (Anderson 2001:53) can only take meaningful form and power insofar as Christian religious leaders embody and demonstrate the Christopraxis for the reconstruction and mobilization of church, societal and academia life 'as forerunner in the struggle for liberation'(Botman 2000:205).

Christopraxis is thus the 'historical concretization' between 'an act of God (divine praxeology) and an act of humanity 
(human praxeology)', especially 'from the perspective of the poor' (Botman 2000:208-209).

Christopraxis is thus more than a theoretical construct. It is an ontological union with the Trinity embodied and recounted in and through the lives of leaders (Anderson in Root 2014:90). Anderson undergirds Botman's theory of Christopraxis and defines practical theology as 'grounded in Christopraxis as the inner core of its encounter with the Spirit's ministry in the world':

$[\mathrm{It}]$ is the normative and authoritative grounding of all theological reflection in the divine act of God consummated in Jesus Christ and continued through the power and presence of the Holy Spirit in the body of Christ. (Anderson 2001:52-53)

Anderson, therefore, contends that practical theology is in essence Christopraxis (in Root 2014:89). Hence, Christopraxis as 'the continuing ministry of Jesus Christ in the World' forms the normative basis of reflections in this study (Root 2014). ${ }^{10}$ It determines our worldview, vocation and mission in life. The only way to yield change in the way to live, work and study lies in our collective vision, tendency or motivation and ability to serve God in terms of humanity, through umunthu. The vision of the University of South Africa (Unisa) shares a similar notion, namely: 'towards the African University shaping futures in the service of humanity' (http://tinyurl.com/hcjyp3e).

\section{Practical theology shaping servant leadership in Africa}

The complexity of leadership challenges in Africa calls for a multidimensional educational or interdisciplinary approach (Adhiambo 2012:159). Religious institutions are called upon to develop servant leadership by 'developing the human person physically, intellectually, socially, culturally, economically and morally' (Adhiambo 2012:173). Leaders are therefore tasked to work within an interdisciplinary, interactive and contextual approach with the human, social and natural sciences to redress the current political, social, economic onslaught on the African continent. To attain this, a new attitude for servant leadership by informing, forming and transforming leaders needs to be cultivated:

The church therefore has a great role to champion Servant Leadership that could be adopted in Africa to enhance development so that the dignity of the human person is upheld in the development strategies laid by the African leaders. (Adhiambo 2012:174)

The church therefore has a social ministry as an integral part of its teaching ministry (Rwiza 2008:242). Its primary concern should be social justice, particularly righteousness (Rwiza 2008:243) (cf Dreyer 2002). This is the social ministry of

10.Christopraxis is the assertion that God is first and foremost a minister, revealin God's self (revelation) for the sake of union with humanity (reconciliation) Ministry conditions the for the sake of union with humanity (reconciliation)... Ministry conditions theology, not the reverse... Further, when encountering God's being, one is called not into theory, but praxis (p. 89). The issue at stake is 'how Go encounters people in and through ministry'.... Therefore, to participate in God's being is to be called into the praxis of ministry. The eschatological and practica implication of Christopraxis 'is the sharing in social relationships with others to the depth that their death is shared for the sake of life' (Root 2014:89-91). religious communities to care and protect poor and vulnerable communities in Africa, especially, when the human person is marginalised by social and political structures - when persons are deprived of their power to free themselves from any kind of oppression (Magesa in Rwiza 2008:242-243).

African religious communities, therefore, have a critical social responsibility (Rwiza 2008:243). Hence, Nyerere's (in Rwiza 2008:244) notions about the church as a prophet, constructive criticism and service inform and shape religious communities to 'maintain its critical distance in order to serve as a "conscience" of political, economic and social orientations' (Rwiza 2008:244).

The perspective of servant churches or religious organisations challenges the current practices of political leaders in Africa who regard themselves as 'kings and chiefs', as referred to above. Religious communities have a moral educational and inspirational responsibility 'where human dignity is denied to empower people to fight for their human rights' (Rwiza 2008:244). Nyeree's ecclesiological challenge has existential and theological implications for religious communities: 'unless the Church fights against these conditions, which condemn human beings to poverty, humiliation and degradation, it has no reason to exist' (Magesa in Rwiza 2008:244):

With HIV and Aids, malaria and a legion of other diseases engulfing the African population, the Church, cannot claim to be a credible witness of the mission of Jesus Christ if it does not vigorously fight against any humiliation of human life. (p. 245)

Religious communities have an ethical role in the enhancement and achievement of true human and community development or service delivery in this article - as the authentic liberation or cultural revolution of African individuals and peoples (Rwiza 2008:246) (cf Van der Ven 1998):

Development means the integration, growth, and satisfaction of the physical and psycho-spiritual needs of the human person, group of persons and nations in their unique historical-geographical environment [as well as] ecological care. (pp. 245-246)

It is therefore clear that any religious community or leadership role in Africa cannot entertain a narrow spiritual ministry to maintain religious organisations or leadership practices. Religious communities and leadership practices should thus adapt to a holistic integrative and interdisciplinary approach to tackle social, economic, political, psychological and spiritual issues simultaneously (Dreyer 2008).

\section{Practical theology as an interdisciplinary helping science}

In Europe, the pastoral theology of Heitink (1979) serves as an example of how it may inform and instil a lasting moralspiritual formational effect on church leaders, especially during harsh circumstances (cf. Grove 2009). Heitink's (1979:75) notion of a helping relation, encountering the Christian faith community as well as faith and life questions, 
refers to a theological search for the well-being of humanity within the missio Dei (cf. Bosch 2005:392). In the light of complex social challenges, a mere application of the church's practice of service as human support, a helping service and developmental projects as forms of diaconia renders it futile (Davies 2015; Heitink 1979:75; Rafapa 2014; cf. Pieterse 2001). Furthermore, it can stifle the development of authentic intersubjective relationships as a form of koinonia. Diaconia as human support becomes no more than a token or pseudo church practice that does not accept 'the marginalised poor or vulnerable' as integrated members of churches (Ries \& Hendriks 2013:2). Neither can it cross beyond 'conventional activities of charity and immediate relief' for the promotion of effective relational (konionia) development (Swart in Ries \& Hendriks 2013:2).

However, Heitink expanded on his philosophy of practical theology in his 1993 book. Practical theology deals with God's activity through the ministry of human beings (Heitink 1993:6-7). Furthermore, leadership can similarly be viewed as 'an activity rather than a particular position' or someone with certain leadership characteristics (Carrol 2006:129). Servant leadership as an activity is embedded in the lived praxis of communities.

Notice the shift in Heitink's $(1993: 18-19,107)$ understanding of practical theology in the light of his initial pastoral theology theory in 1979 (Heitink 1993:75). It changed from a predominantly clerical and church-based approach to a social science and hermeneutical-empirical approach, with modern society as a key focus, through the mediation of the Christian faith (cf. Immink 2005:10). The shift in his understanding of practical theology characterises a general epistemological and methodological change in practical theology since the 1990s (cf. Ganzevoort 2009). Furthermore, it signifies the development of practical theology, not only with the church or clerical paradigm as fields of study, but the broader society beyond the church. This move is of significance and echoes how practical theologians could define their work within their specific and local contexts, especially as a crisis science (Heitink 1993:14-15).

\section{Practical theology as a hermeneutical science}

Ganzevoort (2009:3) calls for a common ground, namely the hermeneutics of lived religion. Lived religion or living praxis relates to 'the actions and meanings operant in the ways humans live, interact and relate to the divine' (Ganzevoort 2009:4; Immink 2005:11). Hence, practical theology studies 'the field of lived religion in a hermeneutical mode' - focusing on 'the most fundamental processes of interpreting life through endless conversations in which we construct meaning' (Ganzevoort 2009:5). Both the hermeneutical and communicative actions are based on the interplay between ideas, sources and actions in religious traditions or praxis (Firet 1968; Pieterse 2001), in other words, life and our reflection thereof in particular, consists of our understandings, experiences, ideas and communicative practices (Ganzevoort 2009:4; Immink 2005:11).
The hermeneutical approach, therefore, constitutes a core in the development of the critical reflective nature of practical theology or in Marx's words a 'practical-critical activity' (Gibson 2011:137; Swinton \& Mowat 2006:75, 107ff.). Anderson, for instance, captures the core of practical theology theory and defines its hermeneutical function as:

a dynamic process of reflective, critical inquiry into the praxis of the church in the world and God's purposes for humanity, carried out in the light of Christian Scripture and tradition, and in critical dialogue with other sources of knowledge. (2001:22)

Browning (in Anderson 2001:26), on his part, defines practical theology as a reflective process to describe the theological core of practical living in, for instance, the area of work.

Contextualising practical theology in South Africa, Meylahn (2014:2), on his part, presents an insightful hermeneutical perspective on 'the role of practical theology in terms of violent service delivery protests and industrial action in the context of Marikana'. Meylahn poses the question: 'How can we explain and understand the event, Marikana?' There is, thus, a vibrant relation between practical theology and contemporary crisis scenarios. It is for this reason that Swinton and Mowat (2006:6), like Anderson (2001:22), define practical theology as:

critical, theological reflection on the practices of the Church, as they interact with the practices of the world, with a view to ensuring and enabling faithful participation in God's redemptive practices in, to and for the world. (Swinton \& Mowat 2006:6)

Critical reflection or a hermeneutics of suspicion in, for instance liberation theology, undergirds the same principles as in the latter - 'it will make explicit the values of faith, hope, and love that inspire the praxis of Christians' (Gutiérrez 2014:xxxiii). Note that liberation theology operates within a critical approach without succumbing 'to serve as a Christian justification of positions already taken' (Gutiérrez 2014:xxxiii). It is prudent at this point to clarify the meaning of practices. The concept 'practices' does not relate to 'the application of theology to specific forms of action (of clergy), through the development of particular techniques to enable better teaching, preaching etcetera':

Practices such as prayer, hospitality and friendship contain their own particular theological meanings, social and theological histories, implicit and explicit norms and moral expectations. The ways in which we practice and the forms of practice in which we participate are therefore filled with deep meaning, purpose and direction. (Swinton \& Mowat 2006:17)

Practices are therefore theory-laden or meaningful, according to Browning (1996:6). This brings us to the question of the critical hermeneutical practice of service or diaconia in practical theology.

\section{The scientific practice of diaconia}

The practice of service (diaconia) featured traditionally under the domain of diaconology. It resurfaced recently at the University of Free State as a sub-discipline of practical 
theology. The need for renewed reflection on diaconology as a sub-discipline of practical theology, in this article, especially within contexts where an ethic of service vacuum exists, is important. Traditionally diaconology was regarded as the theological science of the practice of service (diaconia). It is in essence theology and correlates to all the other theology disciplines in terms of a Christopraxis perspective (Bam 1984:6). Christopraxis comprises the whole of theology (Anderson 2001:52-53; Bam 1984:6).

Bam's definition correlates with that of Anderson (2001) who describes:

the praxis of Christ's ministry in the first century as a completed or fulfilled action or telos in and through his resurrection and continued through the gift of the Holy Spirit at Pentecost. (p. 52)

Practical theology is thus grounded in Christopraxis with its core vested in the encounter of the Holy Spirit's ministry in the world as encapsulated in the word of God (Anderson 2001:53). Bam (1984:7) maintains that the word-event and all the functions of the church which relate to it constitute the study of diaconology (Bam 1984:7). Suffice it to say that the value and meaning of the word-event has been lost in how servant leadership challenges are perceived and engaged in. The role of the word and church cannot be disputed; however, it is a narrow and unattainable position if viewed from the complexity of contemporary socio-political and culturaleconomic service delivery practices and protests in South Africa (Lartey 2006:3; Ogletree 1983:86-87). Note, for instance, that the culture of Christian religious leadership is shaped by the integration of four key aspects, namely the Bible and church tradition, lay members and the social world (Carrol 2006:127). A renewed engagement of the word and church is necessary with the social world and ordinary people, especially with reference to servant leadership, in terms of Marx's 'practical-critical activity' and Fanon's 'radical mutation consciousness and search for new language and vocabulary' (cf. Gibson 2011 above).

Diaconology should therefore be understood as science that studies actions for the realisation and sustaining of the relation between God and humans and humans and God, in the Lord Jesus Christ, through the Holy Spirit, as well as the events themselves which emerge through the mediation of those actions (Bam 1984:8). Actions also relate to how the Christian faith is enacted in developing the church and society as a lifelong mission in worldly events (Ogletree 1983:94). Furthermore, practical theology studies faith actions which are culture oriented - a dimension that needs more elaboration in future research projects (Lartey 2013:3). These actions relate to the character of service (Bam 1984:8). The terms serve (diakoneo), service (diakonia/diaconia) and servant (diakonos) are central in the New Testament (Bam 1984:8). Hence, diaconology is derived from the Greek word diakoneo (serve). It refers to the science of service and the actions which serve the coming of God to humanity and humanity to God (Bam 1984:8). Therefore, diaconia relates in essence to Jesus Christ's discipleship:
... for it is rooted in his basic structure of existence as a slave. It is a form of service in which he is not partially but completely committed in the whole of his being before God, and which he discharges not occasionally but continuously in the whole of his existence as a follower of Jesus Christ. (Torrance in Bam 1984:8-9)

Christ renders a service to humanity which he could not do by himself - resulting in the renewal of humanity within a new community (koinonia) of reconciled people. Hence, practical theology engenders faith communities' ability to 'consistently seek the wellbeing of persons through reflective activities of love and service' (Lartey 2006:3). Furthermore, service could be defined with 'aspects of our faith, such as love, justice, and faithfulness'. It is realised in intersubjective relations through an encounter and communion with God and humans, and humans with humans. The core of the praxis of faith is therefore shaped in and through the interaction between God and human beings, and among human beings (Immink 2005:1).

The notion of diaconia as a personal encounter with the neighbour for their well-being is essential for a service ethic (Bam 1984:9). Mbaya (2012:2, 6), on his part, defines diaconia in terms of the notion of 'waiting at table', and 'providing sustenance', while the wide meaning of the term denotes 'the discharge of a long service or obligations'. Table-fellowship engenders 'deeper communion', 'deeper fellowship' or koinonia which binds people spiritually and socially. Through participation and fellowship (koinonia), co-operation is established which leads to service in the form of martyria and diaconia (Mbaya 2012:2, 6). The task of practical theology is, thus, to develop authentic practices of support and help regarding the personal and communal needs of people (Lartey 2006:3, 11). This service relates to an unselfish service ethic. It should characterise each service function in the church and society and demonstrate the realisation and sustaining of the relationship between God and humans, and humans and God in and through Christopraxis.

Hence, the image of the church of the Lord Jesus Christ in this world is that of a servant - servant church with servant leaders. The church serves so that Jesus Christ becomes a reality in the heart of humans, in the heart of the church, so that the Kingdom may come (Bam 1984:10). Osmer (2008:183), in this regard, refers to 'Jesus as the embodiment of God's royal rule in the form of a servant':

Christ redefines the nature of power and authority ${ }^{11}$ by taking the form of a servant ... servanthood is fundamental to the mission of the community of disciples and leadership within this community. (p. 184)

Therefore, the service function of the church and the events it impacts should redefine the study field of service (diaconia) in practical theology as an unselfish and selfgiving science of service. Bam's (1984:10) caution that to speak of practical theology, although it is well established,

11.A reversal takes place. Power as domination, or power over, becomes power as mutual care and self-giving. Power as seeking one's own advantage becomes power as seeking the good of others and the common good of the community (Osmer 2008:191). 
is to devalue theology is thus ungrounded. Farley (1983:20), for instance, emphasises the importance of the theological character of practical theology without losing sight of its broader responsibility to partner with social sciences to address social, cultural and political challenges, more so by disengaging from a static clerical paradigm and engaging with public life in its complexity. The development of practical theology over the last decades demonstrates a rich and vibrant attempt to shape it as a fully theological discipline or science (cf. Pieterse 1994; 1998; Van der Ven 1994). Bam's (1984) contribution offers a much needed emphasis on the meaning of the Word as embodiment of Christopraxis and the lack of, for example, poor service delivery, a weak work ethic and questionable leadership praxis in contemporary society, institutions and churches in South Africa or Africa. The embodiment of what Osmer (2008:191) refers to as the 'reversal of power and authority' in service delivery practices is crucial. It challenges the church or community in becoming 'a contrast society and a catalyst of social transformation'. A contrast society signifies a sign of servanthood and a catalyst agency demonstrates social transformation with new possibilities within a Christopraxis paradigm (Osmer 2008:191-192).

\section{Conclusion}

Clarifying practising practical theology in contemporary South Africa becomes a prerogative of engendering a 'practical-critical activity' for a 'radical consciousness' towards a 'new language and a new vocabulary' (for example, umunthu or servant leadership) of serving humanity by decolonialising institutional knowledge regimes and in shaping the futures of young emerging leaders. Bam (1984:14) and Mbeki's (in Seale 2016:1) concern of failed religious and political (public) leadership to serve according to the word of God and serving the interests of ordinary people should not be juxtaposed. The essence of their concern lies in the God-given obligation of leaders to serve humanity with humility.

Practical theology can, therefore, build a new vision of service through normative research by reconstructing the narrative of service delivery in South Africa and mobilising educational leaders to instil a new service ethic vision. It can also help religious leaders to reconfigure their theology of diaconia. Practical theology can reshape religious and public practices to advance a service ethic of a new vision and obligation. To this end, the current vacuum and fragmented service ethic in South Africa is in need of redress.

\section{Acknowledgements Competing interests}

The author declares that he has no financial or personal relationships which may have inappropriately influenced him in writing this article.

\section{References}

Adhiambo, J.M., 2012, Education: An effective tool for servant leadership in Africa: Education and evangelisation in Africa Ecclesial Review (AFER), AMECEA Gaba Publications-CUEA Press, Eldoret, pp. 157-177.

Anderson, R.S., 2001, The shape of practical theology: Empowering ministry with theological praxis, InterVarsity Press, Downers Grove, IL.

Bam, G., 1984, Diakoniologie - met ' $n$ kort verwysing na genesing as diens van die kerk. Intreerede gelewer op 8 September 1983 by geleentheid van die formele aanvaarding van die amp van Hoogleraar in Diakoniologie in the Fakulteit Teologie, Reeks A No. 48, Universiteit van Wes-Kaapland, Bellville.

Boff, L., 1986, Ecclesiogenesis The base communities reinvent the church, transl. R.R. Barr, Collins Lirturgical Publications, London.

Bosch, D., 2005, Transforming mission. Paradigm shifts in theology and mission, Orbis, New York.

Botman, H.R., 2000, 'Discipleship and practical theology: The case of South Africa', International Journal of Practical Theology 4, 201-212. https://doi.org/10.1515/ ijpt.2000.4.2.201

Browning, D., 1996, A fundamental practical theology: Descriptive and strategic proposals, Fortress Press, Minneapolis, MN.

Carrol, J.W., 2006, God's potters: Pastoral leadership and the shaping of congregations, Eerdmans, Grand Rapids, MI.

Cilliers, J.H. \& Nell, I.A., 2014, 'Seeking a safe haven?: The interaction between religious and social transformations within Dutch Reformed traditions in South Africa', in W. Gräb \& L. Charbonnier (eds.), The impact of religion on socia cohesion, social capital formation and social development in different cultural contexts: Entering the field in international and interdisciplinary perspectives, $\mathrm{pp}$. 93-107, Lit Verlag, Münster.

Davies, N., 2015, 'The savage truth behind the Marikana massacre', Mail and Guardian, 22 May, viewed 12 April 2016, from http://tinyurl.com/jxaa6uw

Department of Education, 1996, Green paper on higher education transformation, Department of Education, Republic of South Africa, Pretoria.

Dreyer, J.S., 2002, 'Justice for the oppressed: The HIV/AIDS challenge', in J.S. Dreyer \& J.A. van der Ven (eds.), Divine justice - Human justice, pp. 85-112, Research Institute for Theology and Religion, UNISA, Pretoria.

Dreyer, J.S., 2008, 'Practical theology and human well-being: An exploration of a multidimensional framework', Practical Theology in South-Africa 23(3), 3-22.

Dreyer, J., 2016, 'Practical theology from the core-serving crisis or service transformation', Inaugural lecture of Prof Gordon Dames, A response by Prof Jaco Dreyer, pp. 1-4, UNISA, Pretoria, 03 November 2016.

Dreyer, W.J., 1987, Die Teologiese Skool van die Nederduitse Gereformeerde Sendingkerk in Suid-Afrika: Proefpreke van sestien teologiese candidate vir die akademiese jaar 1987, UWK Drukkery, Bellville.

Duncan, J., 2016, 'Police fight the nation's protest rights: An escalation of intelligence-led operations and a wish to use military weapons give insight into the increasingly violent strategies of the SAPS', Mail and Guardian, 30 September-6 October, pp. 21

Edusa-Eyison, J.M.Y., 2008, 'Kwesi A. Dickson: The bible and African life and thought in dialogue', in B. Bujo \& J.I. Muya (eds.), African theology: The contributions of the pioneers, vol. 2, pp. 93-121, Paulines, Limuru, Kenya.

Farley, E., 1983, Theologia: The fragmentation and unity of theological education, Fortress Press, Philadelphia, PA.

Firet, J., 1968, Het agogisch moment in het pastoraal optreden, Kok, Kampen.

Furstenberg, J., Robinson, P. \& Cloete, D., 2009, 'So het ons Jaap leer ken...Indrukke van drie vriende', in E. Conradie \& C. Lombard (eds.), Discerning God's justice in church, society and academy, Festschrift for Jaap Durand, pp. 3-24, Sun Press, Stellenbosch.

Ganzevoort, R.R., 2009, 'Forks in the road when tracing the sacred: Practical theology as hermeneutics of lived religion', Presidential address to the Ninth Internationa Association of Practical Theology Conference Chicago, 2009, viewed 3 August 2008, from www.ruardganzevoort.nl

Gemper, B.B., 1991, 'The Protestant work ethic, the spirit of enterprise and the Siegerland mentality', Koers 56(4), 529-540. https://doi.org/10.4102/koers. Siegerland
v56i4.760

Gibson, N.C., 2011, Fanonian practices in South Africa: From Steve Biko to Abahlali baseMjondolo, UKZN Press, Palgrave Macmillan, Pietermaritzburg.

Govender, P., 2016, 'Profs lecture Protest 101: Academics are said to be working with students who are disrupting universities', Mail and Guardian, 30 September-6 October, p. 2

Grove, P., 2009, 'Integriteit in donker tye', in E. Conradie \& C. Lombard (eds.), Discerning God's justice in church, society and academy, Festschrift for Jaap Durand, pp. 201-202, Sun Press, Stellenbosch.

Gutiérrez, G., 1984, We drink from our own wells: The spiritual journey of a people, Orbis Books, Maryknoll, NY.

Gutiérrez, G., 2014, A theology of liberation, 15th anniversary edition, Orbis Books, Maryknoll, NY.

Heitink, G., 1979, Pastoraat als hulpverlening: Inleiding in de pastorale theologie en psychologie, Kok, Kampen.

Heitink, G., 1993, Praktische theologie: geschiedenis, theorie, handelingsvelden, Kok, Kampen.

Hendriks, H.J., 2007, 'Can a leopard change its spots? Long walk to diversity', NGTT $48(1 \& 2)$, viewed 22 June 2017, from http://ojs.reformedjournals.co.za/index. $\mathrm{php/ngtt/article/view/340/654}$ 
Hermans, C.A.M., 2014, 'From practical theology to practice-oriented theology: The study of lived spirituality and lived religion in late modernity', International study of lived spirituality and lived religion in late modernity', International
Journal of Practical Theology 18(1), 1-14. https://doi.org/10.1515/ijpt-2014-0009

Immink, G., 2005, Faith: A practical theological reconstruction, Eerdmans, Grand Rapids, MI.

Institute for Contextual Theology (ICT), 1984, What is contextual theology? ICT Publication, Braamfontein.

Koopman, N., 2008, 'On violence, the Belhar confession and human dignity', Dutch Reformed Theological Journal 49(3\&4), 159-166.

Koopman, N. \& Vosloo, R., 2002, Die ligtheid van die lig: Morele oriëntasie in 'n postmoderne tyd [The lightness of light: Moral orientation in a postmodern time] Lux Verbi, Cape Town.

Kwiyani, H.C., 2013, 'Umunthu and the spirituality of leadership: Leadership lessons from Malawi', Journal of Religious Leadership 12(2), 39-60.

Lartey, E.Y., 2006, Pastoral care in an intercultural world, Epworth, Werrington (Peterborough

Lartey, E.Y., 2013, Postcolonializing God: An African practical theology, SCM Press, London.

Manala, M.J., 2010, 'A triad of pastoral leadership for congregational health and wellbeing: Leader, manager and servant in a shared and equipping ministry', HTS Teologiese Studies/Theological Studies 66(2), Art. \#875, 1-6. https://doi. org/10.4102/hts.v66i2.875

Manala, M.J., 2014, 'Servant leadership: A required leadership model for efficient and effective service delivery in a democratic South Africa', Studia Historiae effective service delivery
Ecclesiasticae 40, 249-266.

Mbaya, H., 2012, 'Friendships and fellowship: Living koinonia, martyria and diakonia in the Corinthian Church of South Africa - From the perspective of social capital', HTS Teologiese Studies/Theological Studies 68(2), \#Art. 1169, 1-6. https://doi. HTS Teologiese Studies/The
org/10.4102/hts.v68i2.1169

Mentor, I.J., Boesak, A.A., Apollis, N.A. \& Sinclair, P.W.L., 1982, Draft confession of the Dutch reformed mission church in SA, Paarl Drukpers, Hugenot.

Meylahn, J.-A., 2014, 'Imagining the beauty and hope of a colourful phoenix rising from the ashes of Marikana and service delivery protests: A postfoundational practical theological calling', HTS Teologiese Studies/Theological Studies 70(1) Art. \#2616, 1-6. https://doi.org/10.4102/hts.v70i1.2616

Munusamy, R., 2017, 'Pravin Gordhan and Mcebisi Jonas: The faces of the resistance', viewed 4 April 2017, from https://www.dailymaverick.co.za/article/2017-04-01 pravin-gordhan-and-mcebisi-jonas-the-faces-of-the-resistance/\#.WONv9E3ovIU

Mwambazambi, K., 2013, 'Kä Mana: Champion of the theology of reconstruction', in B. Bujo (ed.), African theology in the 21st century, vol. 3, pp. 149-169, Paulines. Limuru, Kenya.

Ogletree, T.W., 1983, 'Dimensions of practical theology: Meaning, action and self', in D.S. Browning (ed.), Practical theology, pp. 83-101, Harper \& Row, San Francisco, CA.

Okambawa, W.K., 2013, 'Efoé-Julien Pénoukou: A theologian's critical approach to inculturation', in B. Bujo (ed.), African theology in the 21st century, vol. 3 , pp. 104-117, Paulines, Limuru, Kenya.
Osmer, R.R., 2008, Practical theology: An introduction, Eerdmans, Grand Rapids, MI.

Pieterse, H.J.C., 1994, 'The empirical approach in practical theology: A discussion with JA van der Ven', Religion and Theology 1(1), 77-83. https://doi.org/ 10.1163/157430194X00079

Pieterse, H.J.C., 1998, 'Practical theology in South Africa', International Journal of Practical Theology 2, 155-165.

Pieterse, H.J.C., 2001, Preaching in a context of poverty, UNISA, Pretoria.

Pui-lan, K., 2005, Postcolonial imagination and feminist theology, Westminster John Knox Press, Louisville, KY.

Rafapa, L., 2014, 'Rethinking Marikana: Warm and cold lenses in plea for humanity', Journal of Literature Studies 30(2), 1-20. https://doi.org/10.1080/ 02564718.2014

Ries, J. \& Hendriks, H.J., 2013, 'Koinonia en diakonia as 'n missionale koninkryksdans', HTS Teologiese Studies/Theological Studies 69(2), Art. \#1249, 8 pages. https://doi. org/10.4102/hts.v69i2.1249

Root, A., 2014, 'Evangelical practical theology', in K.A. Cahalan \& G.S. Mikoski (eds.), Opening the field of practical theology: An introduction, pp. 79-96, Rowman \& Littlefield, Lanham, MD.

Rwiza, R., 2008, 'Laurenti Magesa: An African liberation theology', in B. Bujo \& J.I. Muya (eds.), African theology: The contributions of the pioneers, vol. 2, pp. 231-255, Paulines, Limuru, Kenya.

Seale, L., 2016, Mbeki: This is SA's age of despair, viewed 21 April 2017, from http:// www.iol.co.za/news/politics/mbeki-this-is-sas-age-of-despair-2088225

Smit, D., 2009, 'In die geskiedenis ingegaan', in E. Conradie \& C. Lombard (eds.), Discerning God's justice in church, society and academy. Festschrift for Jaap Durand, pp. 131-166, Sun Press, Stellenbosch.

Smit, D., 2012, 'In search of a grammar for life together? Remembering two decades of doing theology at the UWC', paper presented at the Conference: Towards Histories of South African Intellectual Traditions: The Histories and Life Trajectories of Coloured/'Coloured' Intellectuals. An Interdisciplinary Conference, Faculty of Theology, Stellenbosch University, 30 November-1 December, pp. 1-12.

Swart, I., 2013, 'South Africa's service-delivery crisis: From contextual understanding to diaconal response', HTS Teologiese Studies/Theological Studies 69(2), Art. \#1996, 1-16. https://doi.org/10.4102/hts.v69i2.1996

Swinton, J. \& Mowat, H., 2006, Practical theology and qualitative research, SCM Press, London.

Van der Ven, J.A., 1998, Formation of the moral self, Eerdmans, Grand Rapids, MI.

Vellem, V., 2015, 'From mission to stewardship: The social analysis of Black Mission in the context of Empire', in F.H. Chimhanda, V.M.S. Molobi \& I.D. Mothoagae (eds.), African theological reflections: Critical voices on liberation, leadership, gender and eco-justice, pp. 86-103, UNISA (RITR), Pretoria.

Whittles, G., 2016, 'Violence stirs pot of varsity turmoil: Campuses flared up as police and private security guards clashed with students', Mail and Guardian, 30 September-6 October, p. 3. 